\title{
Coal waste management practices in the USA: an overview
}

\author{
Yoginder P. Chugh $\cdot$ Paul T. Behum
}

Received: 5 July 2014/Revised: 30 July 2014/ Accepted: 2 August 2014/Published online: 11 October 2014

(C) The Author(s) 2014. This article is published with open access at Springerlink.com

\begin{abstract}
This paper provides an overview of coal waste management practices with two case studies and an estimate of management cost in 2010 US dollars. Processing of as-mined coal typically results in considerable amount of coarse and fine coal processing wastes because of in-seam and out-of-seam dilution mining. Processing plant clean coal recovery values run typically $50 \%-80 \%$. Trace metals and sulfur may be present in waste materials that may result in leachate water with corrosive characteristics. Water discharges may require special measures such as liner and collection systems, and treatment to neutralize acid drainage and/or water quality for trace elements. The potential for variations in coal waste production and quality depends upon mining or processing, plus the long-term methods of waste placement. The changes in waste generation rates and engineering properties of the coal waste during the life of the facility must be considered. Safe, economical and environmentally acceptable management of coal waste involves consideration of geology, soil and rock mechanics, hydrology, hydraulics, geochemistry, soil science, agronomy and environmental sciences. These support all aspects of the regulatory environment including the design and construction of earth and rock embankments and dams, as well as a wide variety of waste disposal structures. Development of impoundments is critical and require considerations of typical water-impounding dams and additional requirements of coal waste disposal impoundments. The primary purpose of a coal waste disposal facility is to dispose of unusable waste materials from mining. However, at some sites coal waste impoundments serve to provide water storage capacity for processing and flood attenuation.
\end{abstract}

Keywords Coal waste Coarse coal processing waste $\cdot$ Fine coal processing waste $\cdot$ Coal refuse $\cdot$ Out-of-seam dilution . Dilution impacts · Environmental impacts · Reclamations

\section{Coal waste management issues in USA}

\subsection{Introduction}

Since the increased mechanization of surface and underground coal mining, the proportion of out-of-seam dilution (OSD) mining from immediate roof and floor strata and generation of more fines in the mined product has increased. The focus has been on improving productivity with higher

Y. P. Chugh $(\bowtie)$

Mining and Mineral Resources Engineering, Southern Illinois

University, Carbondale, IL 62901, USA

e-mail: ypchugh1940@gmail.com

P. T. Behum

Office of Surface Mining, Alton, IL, USA advance rates with increasingly larger equipment without attention to OSD or product size. The recent decline in coal production in the US (Fig. 1) will in the near term reduce innovation as the industry will avoid risk. Due to this decline, the average production per employee hour actually decreased by $0.2 \%$ in 2012 (EIA 2013) reversing a long-term trend toward improved productivity. In addition there has been an increase in public attention on the safety and environmental impacts of surface and underground coal mining that is affecting recent trends in coal waste management.

\subsection{Evolving coal mining trends and practices}

Although surface mining still accounts for the largest percentage in coal production in the US $(\sim 50 \%)$, coal mining trends reflect a gradual shift back to underground 


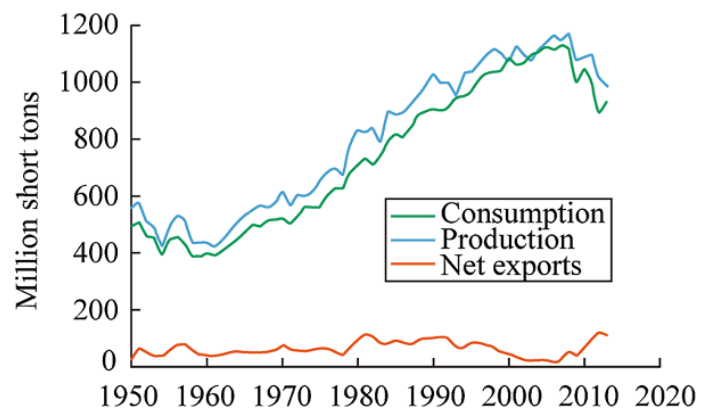

Fig. 1 Trends in US coal production, consumption and net exports (1950-2013). Source U.S. Energy Information Administration, Quarterly Coal Report (March 2014), preliminary 2013 data

mining of bituminous coal since economically mineable surface reserves are depleting in a number of regions. For example, Illinois has had a large increase in productive capacity of $27.3 \%$ in 2012 mostly from growth of new underground mines (EIA 2013).

Bituminous coal mined by longwall methods has gradually grown from $45 \%$ of U.S. underground coal production in 1999 (NRC 2002) to $53 \%$ in 2012 (EIA 2013) of the underground mined coal. Most of this production uses large longwall shearers cutting moderately thick coal beds $(>2 \mathrm{~m})$. The remaining underground production comes from mines with continuous miners using room-and-pillar methods and often employing the "super-section layouts" for increased productivity (Chugh 2007). The increased cutting capability of modern mining machines combined with a gradual decrease in coal seam thickness has resulted in an increase in the OSD in the run-of-mine (ROM) coal. Therefore, the amount of coal waste has increased. Most of the OSD is associated with mining of immediate roof strata. However, in the Interior Coal Basin in the Midwestern USA as much as $0.25 \mathrm{~m}$ of dilution actually comes from the mining of the floor due to weak floor strata below the coal seam. In most mines there exist opportunities to significantly improve mine profitability and improve coal quality through reductions in OSD. The sulfur content of bituminous US coals varies geographically. Lower sulfur coals are mined in Central and Southern Appalachia as premium metallurgical and steam generation. Interior Basin bituminous coals are generally high sulfur $(\sim 2 \%)$ and are exploited for power generation. Western subbituminous and bituminous coals are generally lower in sulfur and used primarily for power generation.

Processing of mined product to meet customer requirements is common and necessary. Current bituminous coal cleaning technologies for coarse coal employ density separation while fine coal cleaning applies surface chemistrybased methods, (Demir et al. 1999). Processing plant recoveries in the US range $50 \%-80 \%$ depending upon seam thickness and associated strata in the roof and floor with typical values around $60 \%-65 \%$. The $35 \%-40 \%$ reject material consists of two components: coarse coal processing waste (CCPW) larger than 100 mesh (150 micron) size or in some cases larger than $3 \mathrm{~mm}$ (1/8 inch) size, and fine coal processing waste (FCPW) or slurry generally less than 100 mesh sizes. The term "coal refuse" refers to coal processing waste and reject from rotary breakers prior to the ROM coal entering the processing plant circuits. The ratio of CCPW/FCPW varies depending upon the mining site but the ratio of $2.5: 1$ by weight is typical. Current processing trends tend to increase the top particle size reporting to the fine circuit to be about 10 mesh to reduce the load on the intermediate size circuits or to allow processing of the entire +10 mesh fraction using a single processing unit operation. This will lead to higher amounts reporting to fine circuits which typically use inefficient technologies for recovering the coal. Some processing plant operators have opted to dispose fine material due to the lack of technologies available for treating moderately difficult-to-clean fine coal and for dewatering of the final product. The result of these practices would be increased number of FCPW ponds (slurry ponds) containing a significant amount of recoverable high purity carbon material (Black et al. 1996; Beck 2007).

The CCPW is typically disposed dry as valley fills in mountainous regions and in embankments to develop impoundment structures in the Interior Coal Basin for wet disposal of FCPW as discussed later. Since about $30 \%-40 \%$ of the mined product must be managed as waste, coal waste management is a very important part of the cost of the mining operation particularly when you consider the environmental impacts of coal waste. Furthermore, both CCPW and FCPW may contain a large percentage of pyrite that can oxidize to generate acid-drainage, elevated levels of sulfate in water discharges, and trace metals.

\section{Impacts of out-of-seam dilution on operations: an review}

Out-of-seam mining has a pervasive impact (Fig. 2) on each step of the coal production process (Chugh et al. 2013). In addition to the more obvious impact of dilution on face production cost, dilution also negatively impacts the cost of all downstream processes. Dilution arising from mining the roof is typically much higher than coal or floor. It results in an increased power cost as well as increased maintenance and wear cost on all the downstream equipment. Dilution affects mine transportation cost by decreasing the belt life and increasing power usage on belts for transporting waste material. Processing cost is impacted as a result of the added dilution material flowing through the processing plant which is eventually rejected at an 


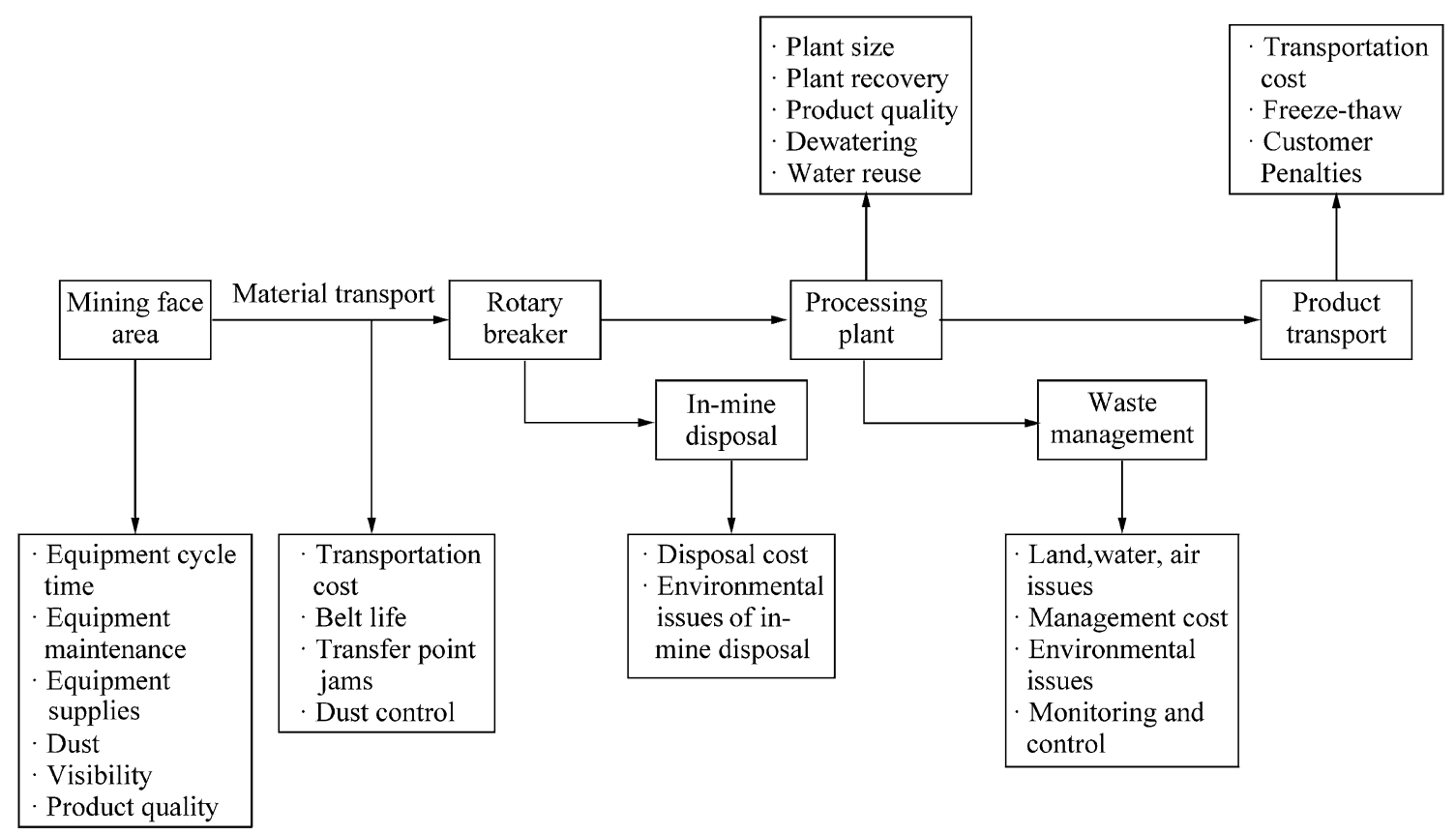

Fig. 2 Effect of OSD mining on production operations

additional cost of increased capital and labor expenditure on construction, maintenance and reclamation of disposal areas.

Some less obvious, but significant, impacts of dilution on coal processing are related to the clays from floor and the carbonaceous black shale roofs. The clays from the floor impact the processing operation in three different ways. These are: (1) Increased clay flowing through the processing plant can increase the viscosity of the medium in dense media circuits. This can aid media stability at low gravities. However, for higher gravity cut points, increased viscosity is detrimental as it decreases separation efficiency; (2) increased clay also implies higher thickening and dewatering cost along with correspondingly higher flocculant costs for water clarification; and (3) higher clay content also impairs the ability to clean and dewater ultrafine coal $(<100 \mathrm{mesh})$ which is a potentially recoverable resource to the order of about $5 \%$ of the raw coal production.

A cost impact of OSD, which is not very well researched or understood, is the impact it may have on clean coal quality. Conventional wisdom suggests that OSD being heavier than coal gets rejected in the preparation plant and does not impact clean coal quality. However, density separation in preparation plants is not a $100 \%$ efficient process. Some of the heavy material may misplace to the float and some of light material may misplace to the sink. Even though the misplaced percentages are small for heavymedia systems, the high amount of OSD in the ROM coal can still cause a significant amount of this material to report to the clean coal. The impact can be particularly severe when lighter OSD materials such as carbonaceous (black) shale ( $\mathrm{SG} \sim 1.8$ ) associated with No. 6 coal seam in Illinois or similar lithologies are encountered. On top of this, the OSD material is known to contain significantly higher amounts of pyrite, mercury and other trace elements (Gluskoter et al. 1977). Therefore, due to this misplaced OSD material reporting to the clean coal product, the impact on product quality and hence the cost can be very high. Luttrell et al. (1996) has analyzed the effect of OSD on blending operations.

The environmental impacts of OSD include: (1) Potential degradation of surface and ground water quality due to pyrite oxidation, dissolution of soluble salts, cation exchange reactions, mobilization of trace elements; erosion and sedimentation of freshly reclaimed soils due to freshly reclaimed soils and slopes, (2) possible increased air quality impacts due to a higher percentage of sulfur in roof and floor rocks, along with higher volatile trace elements such as mercury, arsenic, and hazardous air pollutants; (3) spontaneous combustion of carbonaceous materials in waste and high air permeability of coal waste piles, (4) low fertility of reclaimed lands composed of acid- or toxicforming materials, (5) highly compacted waste piles that 
negatively impact root penetration and growth. In many cases proper mining, processing, and waste management, reclamation practices and clean-coal combustion methods can minimize these impacts, but at an appreciable higher cost.

\section{Impacts of CCPW, FCPW, and refuse characteristics coal waste management}

\subsection{Background}

Refuse or spoils generated during either underground or surface coal mining can be sources of sulfate and chloride discharges with trace elements of concern. Hence, their site-specific physical, chemical, and geotechnical characteristics can have a significant effect on the final quality of the surface water discharges. The construction of refuse/ spoil storage areas, and sediment ponds should be always based on optimum geotechnical properties to ensure public safety. The size, shape and construction methods/equipment for CCPW, refuse, and FCPW piles/ponds are guided primarily on safety against failure of such a structure and are subject to stringent Mine Safety and Health (MSHA) regulatory requirements. During and after construction of the above structures, geotechnical characteristics control the rate of geochemical processes such as oxidation and hydrolysis reactions by limiting the availability of oxygen and water. This is primarily achieved by engineering the amount of compaction and moisture of the waste fill. However, in the process surface run-off may be increased.

\subsubsection{Particle size}

Particle size distribution of waste affects the size of disposal structure. Particle sizes and their distribution control the compaction characteristics, including maximum compaction density that may be achieved during the disposal, and selection of appropriate compaction equipment. This in turn affects permeability of the waste to any leaching fluid. Particle gradation changes upon weathering and affects both size and porosity and permeability. This characteristic should be considered in planning reclamation.

\subsubsection{Permeability}

Permeability of the waste controls the water table, drawdown curve, migration of contaminants out of the waste piles, and oxidation rates. The embankment slopes that are generally not as well compacted have a much higher air and water permeability and this can lead to increased pyrite weathering and sulfate discharge. These discharges, rich in ferric iron (powerful oxidant) typically seep into
FCPW or slurry disposal areas and can accelerate slurry oxidation and acidification at least in areas adjacent to the slopes. Since the water holding capacity of compacted CCPW is low, and the replaced soils are likely to be affected by upwardly migrating salts, the vegetation after reclamation can become stressed and over the long-term degraded.

\subsubsection{Geochemical characteristics of waste/spoil}

Different types of waste generated from a processing plant have different geochemical characteristics and the ratios in which they are generated affect rate of acidification and ultimate sulfate discharge levels. $\mathrm{pH}$ values of waste may range 2-3 in Illinois mines and depends upon the pyrite content. Physical characteristics such as size and shape of particles also affect geochemical processes. Similarly, overburden spoils generated during a surface mine operation may have different characteristics than coal processing waste. Total sulfur content values vary regionally and values ranging from $0.88 \%$ to $6.22 \%$ have been reported in eastern Kentucky and northern West Virginia; $2.27 \%-6.85 \%$ in Illinois, and less than $1 \%$ West Virginia (Daniel and Stewart 2000).

\subsubsection{Oxidation and weathering and neutralization potential of refuse}

Most of the OSD and refuse materials have some inherent neutralization potential (NP) associated with them. However, this potential may be offset by acidity generated during pyrite weathering. Therefore, fresh coal processing waste which still contains most of the inherent NP typically generates a higher $\mathrm{pH}$ discharge with net alkalinity as compared to weathered refuse. However, at this $\mathrm{pH}$ the pyrite oxidizing bacteria are still active and some sulfate generation continues. At most mines pyrite oxidation plays a major role in generation of sulfate. Over time the weathering process breaks down the waste, increases surface area for pyrite weathering and increases sulfate production. Over the long-term upon exhaustion of the pyrite and weathering products (acid salts) the sulfate liberation will finally decline.

\subsubsection{Electrical conductivity (EC)}

Due to oxidation of pyrite in coal waste, soluble salts are present that increase EC and affect vegetation upon reclamation. Daniel and Stewart (2000) reported EC values of $0.03-0.30 \mathrm{~S} / \mathrm{m}$, and $0.2-0.62 \mathrm{~S} / \mathrm{m}$ in waste associated with Illinois mines. Since EC values greater than $0.4 \mathrm{~S} / \mathrm{m}$ can 
affect vegetation for some plants, surface incorporation of limestone to increase the NP is required to reduce EC to appropriate values.

\subsubsection{Elemental analyses}

These have been performed by several researchers and are summarized in (Daniels and Stewart 2000). The primary constituents of the total elemental data include oxides of silica, aluminum, iron, potassium, sodium, magnesium, and calcium. Some of the trace elements include copper, zinc, and nickel.

\subsubsection{Mineralogy}

Although alumino-silicate minerals dominate mineralogy in coal waste, high amounts of carbonaceous materials. Quartz is typically a major constituent. Clay minerals illite, kaolinite, chlorite, and mixed layer clays are common and their percentages vary depending upon the site.

\subsubsection{Chemistry of soil solutions}

These are different for coal wastes and soils. The acids related to pyrite oxidation and resultant salts affect their surface properties. As discussed earlier the release of these salts into solution can affect the vegetation process.

\subsection{Characteristics of OSD at an example Illinois mine}

Physical and chemical characteristics of CCPW, FCPW and coal refuse vary depending upon local surface and subsurface geology and hydrogeology, coal seam and associated roof and floor strata characteristics, and environments of deposition. An analysis of the immediate roof and floor strata characteristics and the coal seam at one mine is discussed below.

Mine 1 sample-A channel sample was collected and included separate samples of roof, coal seam and floor. The measured heights of the three fractions were 25.9, 149.6, $12.7 \mathrm{~cm}$, respectively. Based on specific gravities for these materials of 2.1, 1.4 and 2.6, the percentage of these fractions in the ROM coal were calculated at $18.0 \%$, $71.2 \%$ and $10.8 \%$. A 1.9 density-cut was simulated on this ROM material and the product quantity and quality were estimated (Table 1). The results indicated that a yield of $66.72 \%$ was achieved at a 1.9 specific gravity cut point at an ash content of $7.69 \%$. The sulfur and mercury contents were $0.87 \%$ and $0.092 \mathrm{ppm}$. If only the in-seam material was mined, the mass yield would have been $66.0 \%$ at an ash content of $7.14 \%$ with sulfur and mercury contents at $0.87 \%$ and $0.087 \mathrm{ppm}$, respectively. Hence, it is clear that the additional $0.72 \%$ mass yield came with a $7.6 \%$ increase in ash content and a $6.0 \%$ increase in mercury content in the clean coal. Similarly, As, $\mathrm{Cr}, \mathrm{Pb}$ and Se contents also increased by $7.5 \%, 194 \%$, $1.5 \%$ and $64.3 \%$, respectively.

\subsection{Summary results for all samples-mine 1}

Table 2 lists the average ash, sulfur and trace element contents for all the sampled units and within each of the sampled strata. Typically the roof strata and the 'blue band' (a prominent shale parting often found near the bottom of the Illinois No. 6 coal seam), if present, contain significantly higher concentrations of trace elements compared to either the coal seam or the floor strata. The mercury content in the mined roof is almost three (3) times that of the coal seam. The mercury content in the floor is slightly higher than that in the coal seam. For trace elements like $\mathrm{Cr}, \mathrm{Cd}$, $\mathrm{Sb}$ and $\mathrm{Se}$, the concentrations in the roof strata are one to two orders of magnitude higher than those in the coal seam. These higher concentrations of trace elements in the roof strata are higher than those in the floor despite the fact that the floor ash content is somewhat higher than the ash content of the roof material. These results establish that the concentrations of unwanted constituents in coal such as ash, sulfur and trace elements are higher in OSD and in the roof strata in particular. The concentrations are also significantly higher in the 'blue band' (if present). However, due to the in-seam position of this band, selective elimination of this during mining is not practical. Still, the results indicate that OSD should be minimized to the extent possible.

\section{Regulatory environment}

\subsection{Permit application documentation and process in Illinois}

Federal environmental regulation of coal mining was established by the Surface Mining Control and Reclamation Act (SMCRA) of 1977. Under this act the Office of Surface Mining Reclamation and Enforcement (OSMRE) was established within the U.S. Department of the Interior. The operation permits are issued by Illinois Department of Natural Resources (IDNR), the authorized state regulatory authority under the SMCRA code of federal regulations (30 CFR 731). Water discharge permits are issued by the Illinois Environmental Protection Agency (IEPA) under the authority of the CWA of the U.S. Environmental Protection Agency (USEPA). Other environmental and safety-related approvals are required from state and federal agencies for mining impacts on wetlands, groundwater, and worker safety. Although SMCRA was passed primarily as 
Table 1 Data analysis for Mine 1 channel sample

\begin{tabular}{|c|c|c|c|c|c|c|c|c|c|c|c|c|c|c|}
\hline \multirow{2}{*}{$\begin{array}{l}\text { Roof } \\
\text { S.G. }\end{array}$} & \multicolumn{14}{|c|}{$18.0 \%$} \\
\hline & $\begin{array}{l}\text { Wt } \\
(\%)\end{array}$ & $\begin{array}{l}\text { Ash } \\
(\%)\end{array}$ & $\mathrm{PN}^{*}$ & $\begin{array}{l}\text { As } \\
\text { (ppm) }\end{array}$ & $\begin{array}{l}\text { B } \\
(\mathrm{ppm})\end{array}$ & $\begin{array}{l}\mathrm{Be} \\
(\mathrm{ppm})\end{array}$ & $\begin{array}{l}\mathrm{Cd} \\
(\mathrm{ppm})\end{array}$ & $\begin{array}{l}\mathrm{Cr} \\
(\mathrm{ppm})\end{array}$ & $\begin{array}{l}\mathrm{Hg} \\
(\mathrm{ppm})\end{array}$ & $\begin{array}{l}\mathrm{Pb} \\
(\mathrm{ppm})\end{array}$ & $\begin{array}{l}\text { S } \\
(\mathrm{ppm})\end{array}$ & $\begin{array}{l}\mathrm{Sb} \\
(\mathrm{ppm})\end{array}$ & $\begin{array}{l}\mathrm{Se} \\
(\mathrm{ppm})\end{array}$ & $\begin{array}{l}\text { Wt } \\
\text { Rec }\end{array}$ \\
\hline 1.96 & 5.4 & 52.22 & 23.2 & 25.6 & 20 & 1.14 & 112 & 188 & 0.6 & 43 & 1.68 & 22.1 & 146 & 0.226 \\
\hline 2.08 & 80.3 & 59.81 & 3.3 & 23.3 & 20 & 1.23 & 95.1 & 191 & 0.55 & 40.9 & 1.6 & 19.05 & 138 & 0.475 \\
\hline 2.20 & 14.3 & 68.32 & 0.3 & 21.9 & 20 & 1.24 & 86.7 & 181 & 0.68 & 37.3 & 1.56 & 13.8 & 121 & 0.007 \\
\hline Cumulative & & 57.48 & & 24.0 & 20.0 & 1.20 & 100.4 & 190 & 0.57 & 41.5 & 1.6 & 20.0 & 140 & 0.71 \\
\hline Seam & $71.2 \%$ & & & & & & & & & & & & & \\
\hline 1.28 & 88.5 & 6.29 & 100.0 & 2.7 & 50 & 0.11 & 0.03 & 1 & 0.08 & 15.2 & 0.73 & 0.67 & 2.2 & 63.04 \\
\hline 1.48 & 2.4 & 19.88 & 100.0 & 12.8 & 40 & 0.4 & 0.08 & 1 & 0.27 & 101 & 2.93 & 1.53 & 3.9 & 1.73 \\
\hline 1.55 & 0.7 & 24.53 & 99.9 & 3.6 & 160 & 0.56 & 0.19 & 4 & 0.11 & 4.6 & 2.81 & 0.13 & 3.0 & 0.48 \\
\hline 1.72 & 0.6 & 35.97 & 97.0 & 4.8 & 110 & 0.53 & 1.25 & 4 & 0.16 & 8 & 4.86 & 0.19 & 6.1 & 0.40 \\
\hline 1.76 & 0.5 & 38.98 & 93.2 & 6.9 & 90 & 0.38 & 1.65 & 3 & 0.23 & 14.2 & 7.65 & 0.23 & 7.3 & 0.32 \\
\hline 2.19 & 7.3 & 67.18 & 0.4 & 81.4 & 10 & 0.52 & 0.86 & 1 & 0.46 & 266 & 10 & 2.72 & 6.5 & 0.02 \\
\hline Cumulative & & 7.14 & & 3.03 & 51 & 0.12 & 0.05 & 1 & 0.09 & 17.4 & 0.87 & 0.68 & 2.3 & 66.00 \\
\hline Floor & $10.8 \%$ & & & & & & & & & & & & & \\
\hline 2.02 & 1.3 & 56.39 & 8.3 & 20.6 & 20 & 1.41 & 29.4 & 173 & 0.55 & 37.4 & 1.63 & 16.7 & 104 & 0.012 \\
\hline 2.57 & 98.7 & 92.74 & 0.0 & 2.6 & 10 & 1.8 & 0.32 & 4 & 0.05 & 23.3 & 0.76 & 0.46 & 0.6 & 0.00 \\
\hline Cumulative & & 56.47 & & 20.56 & 20 & 1.41 & 29.33 & 173 & 0.55 & 37.4 & 1.63 & 16.66 & 104 & 0.01 \\
\hline Total & & 7.69 & & 3.26 & 51 & 0.14 & 1.12 & 3.1 & 0.09 & 17.7 & 0.87 & 0.89 & 3.78 & 66.72 \\
\hline Increase $(\%)$ & & 7.6 & & 7.5 & -.66 & 9.3 & 2,222 & 194 & 6.0 & 1.5 & 0.95 & 30.3 & 64.3 & 0.72 \\
\hline
\end{tabular}

Cut point-1.9 SG

* Partition Number calculated from Whitten's equation

Table 2 Average of ssh, sulfur and nine trace element contents in the seam and adjoining strata in Illinois mines

\begin{tabular}{|c|c|c|c|c|c|c|c|c|c|c|c|c|}
\hline Strata & $\begin{array}{l}\mathrm{Wt} \\
(\%)\end{array}$ & $\begin{array}{l}\text { Ash } \\
(\%)\end{array}$ & $\begin{array}{l}\text { As } \\
\text { (ppm) }\end{array}$ & $\begin{array}{l}\text { B } \\
(\mathrm{ppm})\end{array}$ & $\begin{array}{l}\mathrm{Be} \\
(\mathrm{ppm})\end{array}$ & $\begin{array}{l}\mathrm{Cd} \\
(\mathrm{ppm})\end{array}$ & $\begin{array}{l}\mathrm{Cr} \\
(\mathrm{ppm})\end{array}$ & $\begin{array}{l}\mathrm{Hg} \\
(\mathrm{ppm})\end{array}$ & $\begin{array}{l}\mathrm{Pb} \\
(\mathrm{ppm})\end{array}$ & $\begin{array}{l}\mathrm{S} \\
(\%)\end{array}$ & $\begin{array}{l}\mathrm{Sb} \\
(\mathrm{ppm})\end{array}$ & $\begin{array}{l}\mathrm{Se} \\
(\mathrm{ppm})\end{array}$ \\
\hline Roof & 13.53 & 71.55 & 25.77 & 24.35 & 0.93 & 35.21 & 136.3 & 0.29 & 34.97 & 2.77 & 6.21 & 79.59 \\
\hline Top $75 \mathrm{~mm}$ of seam & 3.40 & 9.42 & 1.76 & 166.8 & 0.23 & 0.83 & 4.09 & 0.07 & 2.94 & 1.05 & 0.35 & 4.80 \\
\hline Coal seam-Mid & 75.50 & 12.94 & 4.77 & 106.3 & 0.22 & 0.45 & 2.62 & 0.11 & 12.06 & 2.00 & 0.23 & 2.93 \\
\hline Blue band & 4.83 & 53.10 & 10.27 & 24.29 & 0.19 & 0.17 & 6.08 & 0.39 & 128.3 & 4.75 & 0.22 & 5.10 \\
\hline $\begin{array}{l}\text { Bottom } 75 \mathrm{~mm} \text { of } \\
\text { seam }\end{array}$ & 3.63 & 16.19 & 4.16 & 144.5 & 0.53 & 6.58 & 2.51 & 0.08 & 7.58 & 3.04 & 0.09 & 2.13 \\
\hline Floor & 7.98 & 79.38 & 6.75 & 26.96 & 0.96 & 0.47 & 8.87 & 0.12 & 38.79 & 3.25 & 0.36 & 2.28 \\
\hline
\end{tabular}

environmental legislation, the act authorized an additional set of rules promulgated to regulate the design, review and monitoring of coal waste disposal areas 30 CFR 816.81, and 30 CFR. 816.84. SMCRA sets minimum stability factors acceptable for embankments as well as storm water retention requirements. The regulations require disposal area foundation analysis and consideration of underground mining in the permit submission. The impact of mining on the disposal structure and the structure's impact on the subsidence potential must be analyzed. Coal mine regulation under SMCRA is managed primarily by state and tribal agencies approved for primacy.
Mine permit application process for Illinois coal mining operations, including coal waste management, documents the mining and reclamation practices. These documents contain baseline information about the mine, coal seam, production rates, geologic maps, engineering design, operations plans, revisions, and communications between operators and regulatory agencies. Some of the information contained in the mine permit applications can be used to gain insights into potential sulfate and chlorides discharge issues. The variables that are considered most significant are geo-mining conditions, hydro-geologic information and impact statements made by operators, CCPW, FCPW and refuse characteristics, 
proposed operational and reclamation practices, baseline water quality data, sulfate and chloride water quality discharges data, and other miscellaneous information.

\subsection{Water quality permitting}

Water quality data are needed for the receiving water bodies (typically both upstream and downstream). The parameters that are to be reported at the minimum include $\mathrm{pH}$, total dissolved solids (TDS), total acidity, total alkalinity, hardness, sulfates, chlorides, total iron and total manganese. The coal mine operator must also state whether sulfates and chlorides will be increased in surface or groundwater due to the mining operations. Additional baseline information is required for groundwater present in water bearing strata both up-gradient and down-gradient of the proposed operation. Illinois surface water (Section 620) and groundwater regulations include requirements for the operator to conduct sampling and analysis for the inorganic parameters listed below (Section 620.450, concentrations of chemical constituents applicable to Class I groundwater).

\begin{tabular}{lll}
\hline Antimony & Copper & Radium-226 \\
\hline Arsenic & Cyanide & Radium-228 \\
Barium & Fluoride & Selenium \\
Beryllium & Iron & Silver \\
Boron & Lead & Sulfate \\
Cadmium & Manganese & Thallium \\
Chloride & Mercury & Total dissolved \\
Chromium & Nickel & Solids (TDS) \\
Cobalt & Nitrate as N & Zinc \\
\hline
\end{tabular}

After mining and coal preparation begins, both the CWA required National Pollutant Discharge Elimination System (NPDES) permit issued by the IEPA and the IDNR-DM\&M issued SMCRA permit required (as part of the surface water monitoring program) require water sampling, analyses and reporting of all point source discharge locations (outfalls). Though the sampling method and frequency requirements may vary from permit to permit, typically quarterly samples analyses which include sulfate and chloride for both upstream and downstream stations are required. In addition all outfalls that are discharging during that period are typically sampled nine (9) times a quarter from which the monthly average and daily maximum values are derived.

A coal mine operator may also be required to perform ground water monitoring for sulfates. The wells and springs that are monitored are located inside or within
$0.8 \mathrm{~km}$ of the permit area. The operator also has to report whether there will be any discharges into underground mine workings or whether ground water is being pumped out of the mine. The operator is also required to identify all public water supply sources within $16 \mathrm{~km}$ of the permit boundary and has to list the adverse effects on these water bodies due to the mining activities.

\subsection{Baseline water quality requirements}

Baseline water quality and quantity information establishes pre-mining conditions of water resources. Baseline conditions establish the usefulness of these resources and serve as a gauge for evaluating the impact of coal mining. Most permits reviewed contained considerable baseline groundwater and surface water information, which had details upgradient and down-gradient sulfate and chloride levels in the proposed mining area, as required by current regulations. Unfortunately, baseline surface water quality data was not included in all reviewed permit applications. This may be due to the closed-loop water handling system employed by many Illinois mining operations and the assumption that no water will ever leave the site. This limits the permit reviewers understanding of baseline conditions of the receiving water bodies and the ability of these water bodies to tolerate an increase in sulfate and chloride levels due to coal mining and processing activities. A reviewer requires this knowledge in the preparation of SMCRA required "Cumulative Hydrologic Impact Assessment (CHIA)" and the surface water material damage criteria.

\section{Coal waste management practices}

\subsection{Current trends and regulatory environment in the US}

In many cases coal waste is disposed within impoundments where FCPW (slurry consisting of -100 mesh coal waste with about $15 \%$ solids content) is encased in embankments constructed of compacted CCPW (NRC 2002; MSHA 2009). Alternatively, some facilities place dewatered FCPW (about $65 \%$ solids content) within these embankments. In bituminous coal fields of Appalachia and the Western U.S. high embankments $(>100 \mathrm{~m})$ are constructed across a steep-sided valley, whereas in the Interior coal basin's level terrain a lower, partially incised embankment is constructed that encases the FCPW. At a few U . S. facilities co-disposal of CCPW and dewatered FCPW is practiced which lowers the disposal area footprint and can produce a lower long-term liability if stability requirements are achieved (MSHA 2009). 
The success of dewatering FCPW is the key to emplacement of dewatered FCPW. Disk belt filters and deep cone paste thickeners have been used in this application with mixed success. In some cases powdered limestone additions have been used it as a drying and cementing agent to achieve the proper moisture-density relationship suggested by laboratory testing. These applications have been in some cases limited to sites with concerns regarding potential stability or environmental problems associated with the disposal structure. In general most of the industry avoids mixing different wastes due to permitting and/or a long-term environmental liability concerns.

Safety issues associated with the construction of FCPW impoundments include embankment failures and coal slurry spillage due to subsidence in close proximity mines. Stability concerns started with the Buffalo Creek disaster in 1972, which killed 125 people and injured 1,190 others (NRC 2002) and prompted National regulation regarding coal waste embankment design, construction, operation and closure. Another 32-million gallon coal slurry spill occurred in 1994 near Davella, Kentucky. Here subsidence drained slurry into in a sealed underground mine only about $10 \mathrm{~m}$ below the impoundment. A similar but much more severe slurry spill occurred at a site near Inez, Kentucky in 2000. In this case about 1 million liters of decant water and 130 million liters of FCPW fines drained into a subsidence feature (Stewart and Robinson 1994; NRC 2002). A number of smaller FCPW spills have also occurred in Appalachia (Canon 1981; NRC 2002). Potential environmental impacts of current waste disposal practices are not limited to a relatively few catastrophic events. Implementation of proper management practices is necessary for prevention of groundwater contamination and mitigation of surface water impact to the receiving water body.

Unlike Clean Air Act which had an effect on the overall health and distribution of the coal industry, the Federal Mine Safety and Health Act of 1977 had a direct impact on coal waste management by directly regulating disposal practices. Under this act the MSHA has promulgated rules to regulate the design, review and monitoring of coal waste disposal areas (30 CFR. 77.214, 30 CFR. 77.215, and 30 CFR. 77.216). A professional engineer certified design is required for impounding structures and the location of underground workings in relation to them. MSHA review of the design is in depth and can be lengthy. Requirements for monitoring of the impounding structure are extensive and include inspection by one of the engineers at the mine or another "qualified person" (every 7 days), Federal MSHA inspectors (2-4 times per year), and state inspectors. The MSHA review and inspections are focused on protecting the miners and nearby public for health and safety.

Currently, OSMRE is undergoing a rulemaking effort regarding what was known as the buffer zone or "Stream Protection Rule". It was originally promulgated to replace the existing rule promulgated in 1983, and is now being referenced as the Stream Buffer Zone (SBZ) rule. This rule prohibits the mining-related disturbance within $30 \mathrm{~m}$ of a perennial or intermittent stream to protect aquatic resources unless the activity is specifically authorized based on a determination that the within buffer zone activity will not cause or contribute to a violation of water quality standards or adversely affect the environmental resources of the stream. Additionally, miners wishing to place mine overburden or a cross-valley mine waste impoundment could obtain a general or individual permit from the US Army Corps of Engineers (USACE). In a series of controversial actions, the US EPA has rescinded the 404 permits at Appalachian mines under discretion granted by the CWA.

The CWA 1972 (33 U.S.C. \$1251) authorized a set of regulations (40 CFR 434) that set water quality limits on coal mining-related discharges under the NPDES for point source discharges. These discharges are typically not from the coal waste impoundment itself, but from a down gradient sediment impoundment. Again EPA regulations are implemented in most cases by states that have been granted primacy.

Section 404 of the CWA (33 U.S.C. \$1344) authorized the USACE to approve placement of "fill" material in water courses or "waters of the US". In the past mining related fills such as valley fills and coal waste impoundments have been granted approval under a general "Nationwide Permit Program" without an individual USACE review. To qualify the fill must have "minimal impact" in headwater streams with a flow of less than about $0.16 \mathrm{cu}$. m/sec (NRC 2002). There has been considerable citizen and US EPA concerns with this process. The issuance of general 404 permits (NWP 21) has been significantly reduced Nationwide and halted altogether in Appalachia. Finally, the SAFE Drinking Water Act (SDWA) was passed in 1974. The main impact of the SDWA is regulations that place restrictions under the underground injection control (UIC) program on the injection of coal waste into abandoned mine workings. This is a practice which was commonly used in the coalfields, but is becoming more difficult to practice for both technical and regulatory reasons. Although a number of coal-mining states regulate UIC programs under primacy, some states such as Indiana and Kentucky have declined implementation of at least part of the program and, in these cases the USEPA retains regulatory authority. 
5.2 Current practices around underground coal mines in Illinois

Operations in Illinois use combinations of CCPW embankments, sediment ponds and surface drainage network to minimize adverse environmental effects of waste management, mining, processing, and reclamation activities. Current CCPW (refuse) structures are typically pyramid shaped, stepped structures. Majority of active mines dispose CCPW and FCPW in separate structures. Some operators have their CCPW structures built around FCPW structures at the center. Some operators co-dispose their FCPW and CCPW by mixing them together to take advantage of their geochemical properties. Some CCPW structures are constructed from CCPW mixed with clay or fly ash to improve their compaction and reduce their hydraulic conductivity. After the CCPW and FCPW structures are completed, they are capped by top-soil or sub-soil that have been removed and stored from within or outside the mine permits area. Alkaline amendments are added as appropriate in the upper portions of graded CCPW before putting the soil cover and vegetating it (Daniels et al. 1999).

\subsection{Current practices around surface coal mines in Illinois}

Active surface coal mine operations in Illinois adopt approaches similar to underground mines with regard to the management of overburden spoils. The surface mines also use a combination of spoil pits, surface drainage network and sediment ponds to minimize potential of run-off water contamination. Coal processing waste is typically deposited at the bottom of the pit after removal of coal. This is done prior to dumping of overburden spoils. Overburden spoils are dumped into the pit using shovel or dragline, or hauled to the pit that is typically at the backend of the mining front and dumped. Then, spoils are usually graded with light compaction. Similar to underground coal mines, topsoil and subsoil removed and stored previously are used as cover material and vegetated. Sediment/dilution ponds in a surface mine also collect sediments and leachates, and help to minimize pollution potential. Finally, the ponds are also covered with topsoil and subsoil and vegetated (Rich and Hutchinson 1990).

\subsection{Mining operations factors affecting water quality}

Mining practices around a surface coal mine that affect the surface run-off water quality in Illinois are given below.

- Relative geographic location of surface facilities such as coal processing plant, coal storage yard, coal waste piles, sediment ponds, drainage system affect the water quality at the final discharge locations.

- Haulage, stacking and compaction methods for coal waste disposal affect the weathering process of the refuse and have bearing on the final surface discharge water quality.

- Sediment ponds receiving runoff from coal stockpiles and non-reclaimed coal waste areas contain some sulfate and chlorine-bearing coal and coal refuse particles. During dry periods the sediment ponds may be exposed to air and desiccation effects (acidic sulfate salt formation). However, in Illinois this is generally not an issue with because most sediment ponds do not dry to the point of exposure to air.

- Normal and flood period time drainage plans (i.e., ditches, berms and ponds) of the mine regulate the extent of dilution achieved inside the mine permit boundary before any run-off water is released the receiving water body.

- Design of water holding and fresh dilution water impoundments impacts the ability of the operation to dilute contaminants.

\subsection{Reclamation factors affecting water quality in} Illinois

During the reclamation process, several practices affect the surface discharge water quality.

- Level of compaction achieved during construction of disposal structures and moisture content in the coal waste during the construction process governs the rate of leaching process and discharge of contaminants.

- Amendments such as agricultural lime, cement kiln dust (CKD) and coal combustion byproducts modify both the physical and geochemical properties of the fill and as a result affect both the stability of the structure and the chemistry of any leachate from the facility.

- Characteristics and thickness of final soil cover significantly affects the leaching and contaminant discharge process. Acidic- and sulfate-bearing discharges may be reduced where well-designed, engineered covers are emplaced. These include a compacted layer for limitation of infiltration into the acid-and sulfate-forming material overlain by a higher hydraulic conductivity layer for drainage (the capillary-break layer) and then a noncompacted rooting medium at least $0.6 \mathrm{~m}$ thick.

- Any long-term erosion and subsequent exposure of waste in their respective impoundments may accelerate the oxidation process and discharge of contaminants.

- Contemporaneous reclamation has significant impact on the water quality. Wherever feasible the timely covering and vegetation of acid- and sulfate-forming materials will aid in reducing sulfate discharge. 
5.6 Inter-relationships among factors affecting water quality

There are several factors within the above-mentioned groups that can interrelate with other factors and water quality. For example: (1) Elevated chloride levels can affect sulfate level due to the ion pairing effect, (2) presence of $\mathrm{CaCO}_{3}$ can affect sulfate level, but only under conditions of high $\mathrm{pH}$, calcium and sulfate concentrations, (3) presence of $\mathrm{CaCO}_{3}$ generally does not affect the chloride level, (4) compaction of waste affects its permeability and geotechnical properties.

\subsection{Good coal waste management practices practiced} in Illinois

- Covering of weathered pyrite-rich coal waste with fresh coal waste in a timely fashion to minimize further oxidation. However, this practice is limited because of operational constraints.

- Mixing alkaline waste materials such as CKD or alkaline coal combustion byproducts (Type $\mathrm{C}$ fly ash or fluidized bed combustion ash) in bulk with CCPW prior to disposal to increase base NP and making it relatively impermeable to air and water. However, this practice can only be considered if the practice is economically attractive.

- Elimination of terraces and drainage channels on the inside and outside slopes of disposal structures that collect leachate and allow runoff to infiltrate the structure. Such practices allow increased acidification and sulfate discharge and also negatively impact structural stability.

- Locating dilution lakes and sediment ponds below reclaimed areas to take advantage of good quality fresh water run-off.

- Moving FCPW (slurry) discharge points. However, it may not be done frequent enough to ensure that the pyrite-rich fraction, which is differentially deposited near the slurry discharge point, is encapsulated by clayrich fraction which is deposited farthest from the slurry discharge point. The goal should be to keep FCPW covered with water at all times.

- Proper application of slurry distribution manifold at a few mines could improve distribution of clay-rich FCPW on the top of pyrite-rich FCPW.

- Application of co-disposal of CCPW and dewatered FCPW to take advantage of their NP properties.

\subsection{Inappropriate coal waste management practices in Illinois}

The following practices can increase the pollution potential in the surface discharge water.
- Leaving CCPW exposed to oxidation for long periods without covering it with fresh un-oxidized CCPW and/ or not compacting it.

- Constructing CCPW disposal structures in thick lifts ( $0.3 \mathrm{~m}$ or greater) that result in lower compaction levels and larger air and water permeability.

- Not compacting haul roads and safety berms that can be a source for acid drainage and poor water quality. Although the roadway surfaces are in most cases well compacted and resistant to weathering, some mines have loose, deeply rutted haul roads, and the safety berms and roadway out-slopes are not compacted and are subject to weathering.

- Improper selective placement of CCPW high in the spoil reclamation process for extended periods of time at surface mines and allowing it to oxidize.

- Allowing deltas to form in FCPW disposal ponds without ponded water that would allow oxidation and weathering of the FCPW materials.

- Minimal moving around of the slurry pipe discharge points to distribute pyrite-rich materials over a wide area.

- Minimal compaction of CCPW in some refuse disposal areas especially on and near out slopes and equipment safety berms.

- Lack of systematic blow-down of polluted waters to minimize excessive formation of readily-soluble desiccation salts (i.e., calcium chloride, calcium sulfate, and magnesium sulfate) on fresh coal waste and clean coal surfaces.

\subsection{Water quality management}

A typical coal mine complex (underground mine shafts, drift portals and slopes and their associated coal preparation facilities) operates a closed loop water system. Although rainfall in Illinois greatly exceeds evaporation, a typical underground coal mine and associated preparation plan complex will often operate on net deficit of water during the course of a typical year. This is largely due to water lost during the mining process (dust suppression) and coal washing. Most water exits the facility either as evaporation water or surface moisture on the processed coal. To supplement their needs these operations add water from a fresh water impoundment or groundwater source. Periodic discharges (blow down) will occur typically from a single sedimentation control basin with an NPDES discharge. Often this blow down occurs during a period of high precipitation when waters with high TDS are acceptable. However, the primary need for blow down is to drain water that is detrimental to equipment operation. 


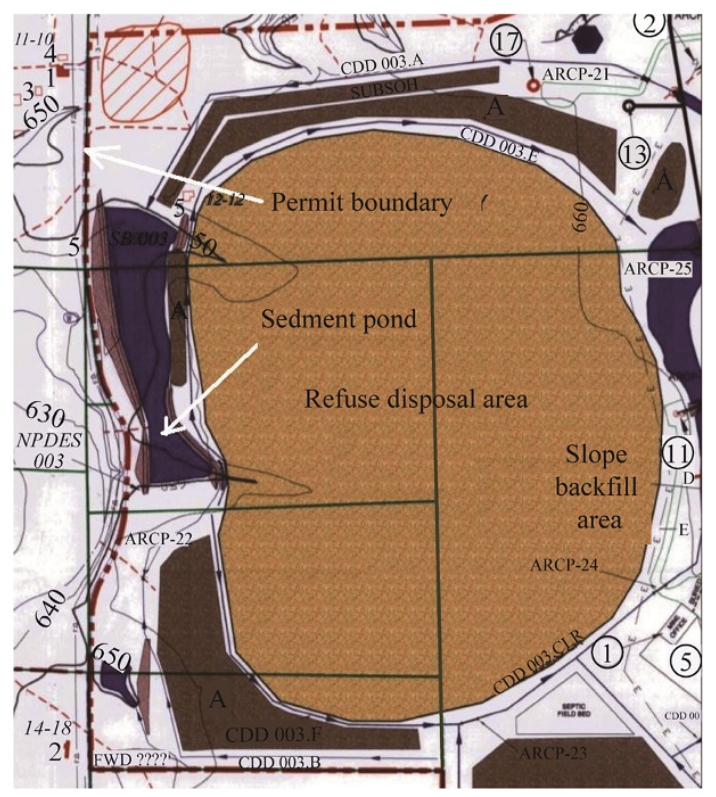

Fig. 3 Typical layout of refuse disposal area, sediment pond and NPDES discharge point

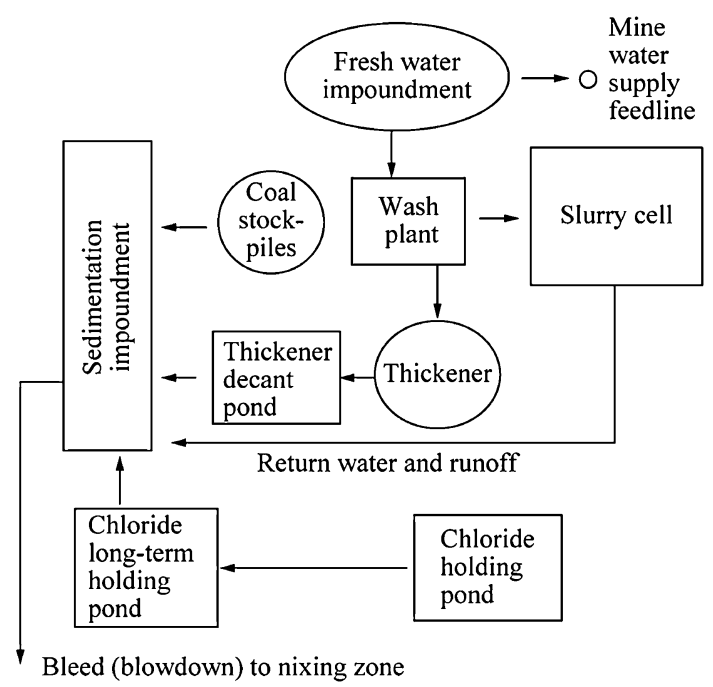

Fig. 4 Typical water-management flow chart for an Illinois mine complex

To supplement the perimeter sedimentation basins additional holding ponds are usually employed to collect runoff from the surface facility and pump discharges from mine workings. The water from these facilities is used in the operation (i.e., fire control and dust suppression systems) and coal handing and preparation facilities (coal washing and dust control, Fig. 3). A large amount of water is also stored in slurry impoundments. Figure 4 shows a typical surface water management system. Here water from refuse disposal areas are routed through a network ditches into sediment impoundment, before it can be discharged outside the permit boundary. Although mine operators apply a number of conventional management practices to control sulfate and chloride discharges, some still have difficulty in controlling the level of these pollutants.

Previous studies have identified a significant relationship between the pollutant discharge levels and precipitation (rainfall and snow) events, which dilute pollutants such as sulfate and chloride levels and lower the discharge concentrations. There is typically a time lag following a large precipitation event and resultant change in the discharge concentration of sulfate and chloride. Important factors that contribute to these changes are site-specific hydrology (i.e., the location of the sampling point in relation to the source of the pollutant), the geochemical environment at the time of precipitation (i.e., a preceding period of desiccation and sulfate and chloride salt formation). Another variable is the timing and quality of water measurement, sampling and analyses. However, the regulatory sampling program protocols are designed to obtain an accurate range of concentrations that sufficiently characterize the discharges from a basin.

\section{Case studies of coal waste management}

\subsection{Introduction}

These are based on visits to both underground and surface coal mining facilities to survey the coal waste management practices as well as based on a review of their mine permits. These visits were made to observe mining, processing, and coarse/fine coal processing coal waste disposal operations and water management at the sites. The above helped to develop an understanding of the relationships that exist among all of the above activities as they impact coal waste management at the mines. During the visits insights from professionals at each mine were obtained and synthesized. The visits also allowed researchers to observe and assess good and not-so-good management practices and develop an inventory of proven good management practices for operators to consider for implementation. Case studies for two mines are presented here.

\subsection{Mine I: mine and processing plant operations}

It is an underground mine that had a production of about 2 million tons of clean coal per year. It mined Herrin seam at depth of about $100 \mathrm{~m}$. The coal is overlain by Anna Shale-limestone sequence in some areas and Energy Shale in other areas. The coal processing waste consists of $20 \%$ in-seam dilution and $80 \%$ OSD, primarily from roof strata. The in-seam pyritic sulfur content is $2.6 \%$, organic sulfur content is $2.64 \%$ and sulfates are $0.25 \%$. There is small variability in sulfur content throughout the mine. The 


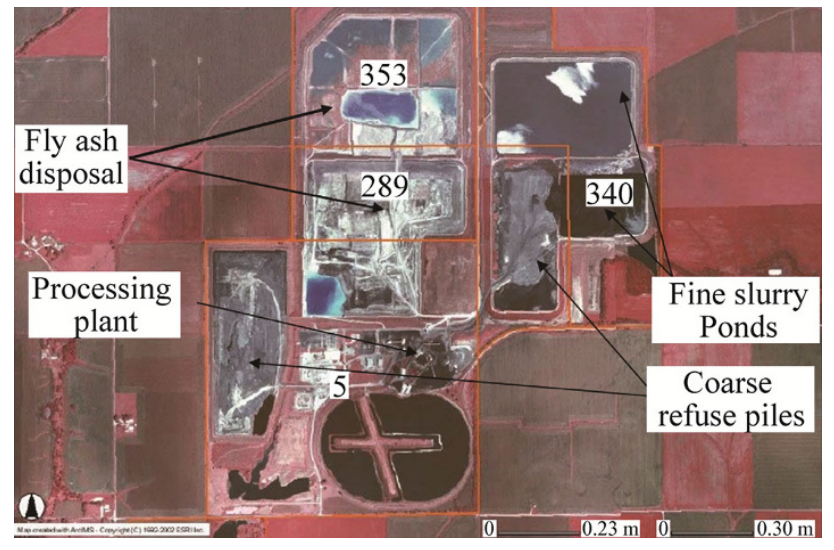

Fig. 5 Mine I aerial photograph

processing plant recovery is about $70 \%$ and 0.85 million tons of refuse is generated every year (including CCPW and FCPW). The distribution ratio of CCPW to FCPW is about 3:1.

\subsection{Mine I: CCPW and FCPW management}

Currently, the mine has two CCPW (coarse refuse) disposal areas and two FCPW (slurry) disposal areas (Fig. 5). The old coarse refuse pile is on the NW side and the new coarse refuse pile is on the NE side of the mine permit area. The older of the two slurry disposal areas is located on the SE side of the old coarse refuse disposal area and it has been covered and neutralized using FBC byproducts. The byproducts are hauled back from 10 different sources and they provide alkalinity for on-site acid drainage neutralization. Previously, CCPW was mixed with combustion byproducts in bulk to amend the NP. Currently, FBC products are managed separately from CCPW. However, highly alkaline water from the byproducts is available for use to neutralize acid drainage (AMD), if needed.

\subsection{Mine I: water management}

The water management network employs a closed loop system, which maintains and isolates all AMD and combustion byproducts disposal runoff within the active operation. Coal processing plant receives fresh water from a nearby creek and also from the run-off circuit. Run-off water from the old refuse pile reports to a settling pond. A few structures screen the run-off before it is pumped to the clarified water pond. Excess water from the coal processing plant is used to deliver combustion byproducts in a slurry form to the disposal area. Decant water from the fine refuse disposal areas on the NE side of the permit acts as the surface make up water for byproducts delivery. Water coming out of the preparation plant is also used to deliver the FCPW into the slurry pond on NE side of the mine permit area.

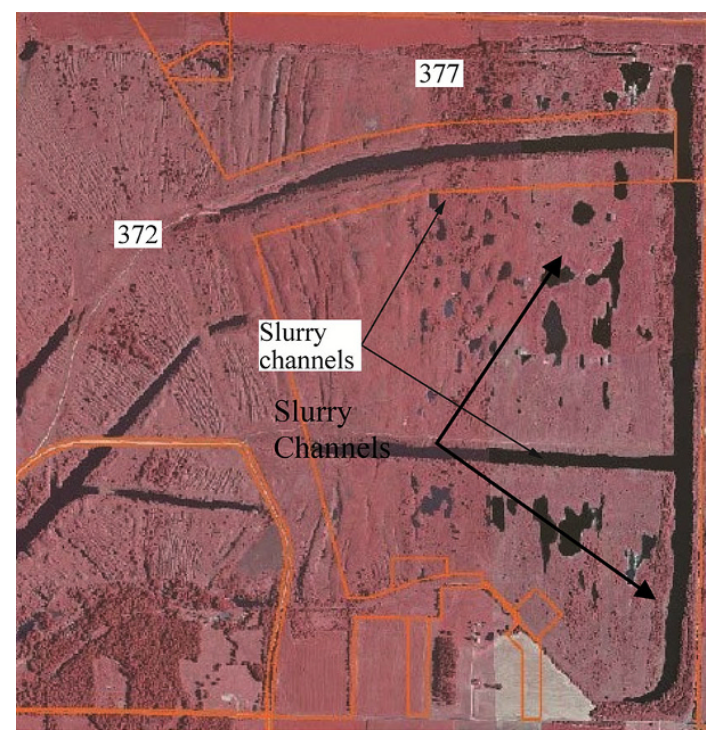

Fig. 6 Mine II aerial photograph and coal waste management facilities

\subsection{Mine II: mine and processing plant operations}

It is a surface mine in southern Illinois that produces about 4 million tons of clean coal per year and 1 million tons of coal processing waste per year. The mining depth is $30 \mathrm{~m}$ and the coal seam (Murphysboro seam) being mined has thickness of $1.8 \mathrm{~m}$. The mine has shale and limestone as roof and claystone as floor. Coarse refuse (CCPW) is based on a mixture of bone coal and shale parting material with a small amount of dark shale, and large amount of relatively coarse, light gray-color claystone fragments. Large amounts of coarse-grained pyrite is observed as bands in mined coal. Fine refuse (FCPW) is also rich in fine-grained pyrite as observed around the FCPW pipe discharge area. A portion of the coal from this site is mined with a high-wall miner system from a box cut. This system employs an underground mining-type continuous miner that is remotely operated from the surface. As a result this mine produces ROM coal that has a higher OSD than a typical Illinois surface mine.

\subsection{Mine II: CCPW and FCPW management}

CCPW materials at this mine are hauled back into adjacent surface mine pits before covering them with overburden spoil. Overburden material is hauled back in trucks and placed on the top of CCPW, before covering both the CCPW and overburden with stockpiled top-soil and subsoil. Overburden material separates based on size due to end dumping from haul trucks. Large (mostly alkaline limestone material) rolls to the bottom while the finer material (more likely to be acid-producing) stays close to the top of the embankment. The FCPW slurry cell is 


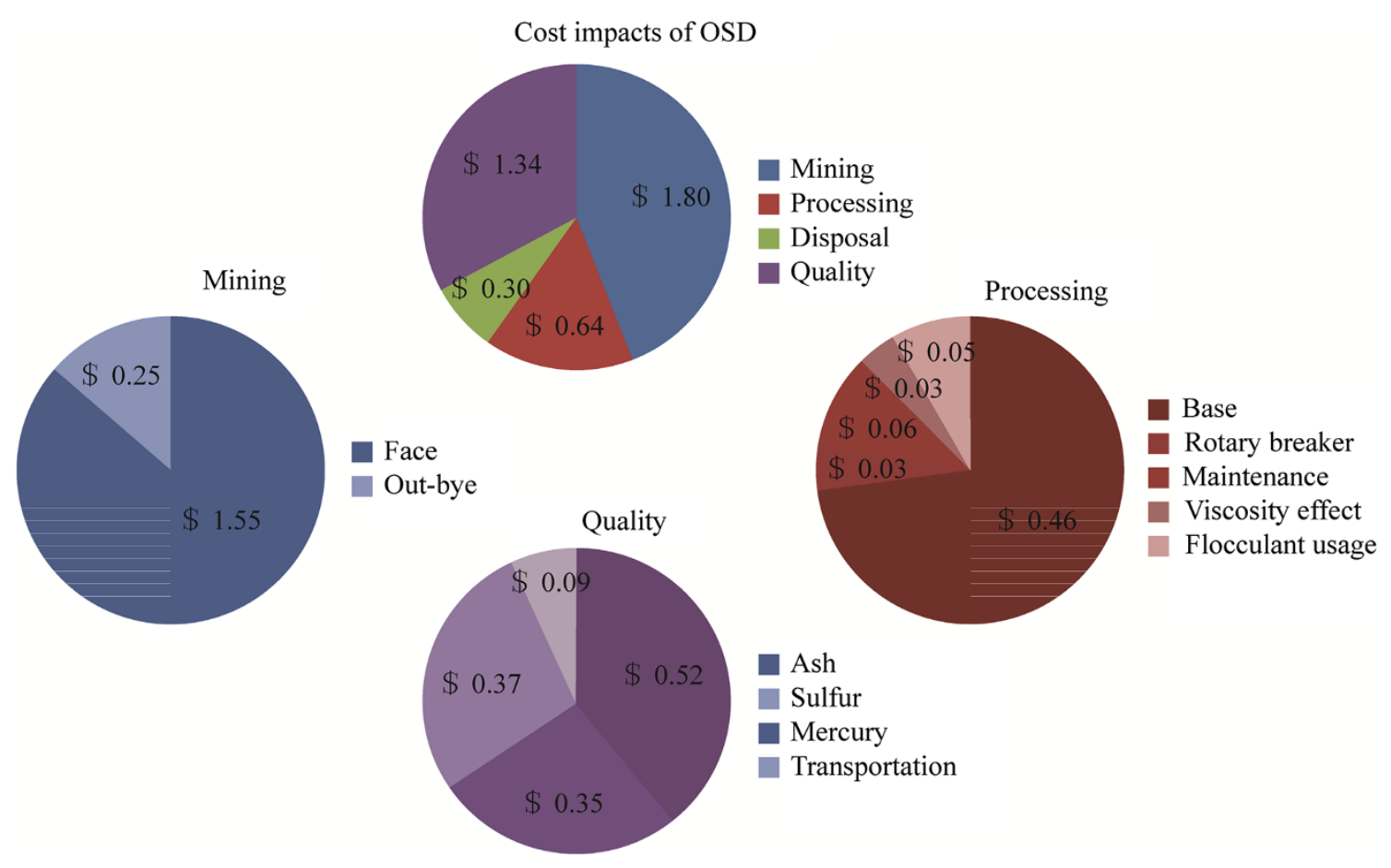

Fig. 7 Cost impacts of OSD in total and broken down by components

located over the west side of the mine and receives slurry from the preparation plant (Fig. 6). Typically, no water discharge occurs at NPDES points from this mine permit area.

Preparation plant is rated at $500 \mathrm{~m}$ ton/h. FCPW material is pumped as $7 \%$ solids slurry into an old haulage ramp from the open pit. The FCPW fines segregate with distance from the discharge point. Pyrite and other heavier fines segregate near the top of the old haul ramp. Significant amounts of FCPW material is exposed to atmosphere but it is in a saturated or semi-saturated condition, closer to the point of discharge.

\subsection{Mine II: water management}

One large diameter pipe discharges $7 \%$ solids concentration FCPW slurry into an old final pit impoundment to form a slurry cell. The decant water from the FCPW is pumped back to the preparation plant through three large diameter pipelines. Pumping is also done from the box-cut and highwall faces, and water from these sources goes to different sumps. Typically, no slurry fines or water discharge occurs at NPDES points from the permit area due to the presence of an earthen barrier across the impoundment and the large amount of percolation through the old surface mine spoils.

\subsection{Cost-impacts of OSD mining}

Patwardhan et al. (2010) presented the effect of OSD on mine economics (2010 dollars) for a typical Illinois coal mine with average OSD mining characteristics, average OSD quality and average product quality changes due to OSD as presented in Table 2. Quality impacts of the OSD originating from the roof and floor strata were separately estimated. The total quality impact on cost was estimated as $0.87 \$ /$ ton of clean coal. Since the average yield in Illinois coal preparation plants is $65 \%$, the above cost translates into $1.35 \$$ /ton of ROM coal. To express this cost in terms of tons of roof and floor mined, it needs to be realized that the ash and transportation related impacts are applicable to both the dilutions arising from the roof and the floor. The sulfur and mercury related impacts are, however, primarily related to roof dilution. Given that the average mined roof and floor strata form $13.5 \%$ and $8 \%$ of the ROM, respectively, the cost impacts translate into $5.63 \$ /$ ton of roof material and $1.39 \$ /$ ton of floor material mined. Figure 7 presents the detailed sources of costs incurred due to mining OSD. It can be seen that the loss in productivity from mining out-of-seam material is the single biggest contributor to the cost. This cost is somewhat understood by the industry. The second largest contributor to the OSD cost impact is the impact of deteriorating clean coal quality due to the presence of OSD in ROM coal. This 
impact has largely been ignored by industry and researchers. Additional costs incurred due to OSD in order of importance are in the processing and disposal operations (Stewart and Daniels 1995; Stewart et al. 2001).

\section{Conclusions and remarks}

This paper has provided an overview of OSD mining and associated coal waste management practices, including the regulatory environment. An attempt is also made to analyze the impact of OSD on the associated costs. This paper provides an overview of the importance of OSD control which has been overlooked for too long. This is particularly important when environmental groups are carefully evaluating the performance of mining industry in terms of environmental performance and quality of water discharges. It is clear that to enhance the competitiveness of the coal industry, efforts need to be devoted to reducing OSD. This accomplishment can improve the marketability of coal as a lowest cost and clean burning fuel of choice through lower production cost and better product quality.

Acknowledgments The authors sincere acknowledge the funding support by the Illinois Clean Coal Institute and the Department of Commerce and Economic Opportunity, and the support at the cooperating mines for providing high quality data included in this paper.

Open Access This article is distributed under the terms of the Creative Commons Attribution License which permits any use, distribution, and reproduction in any medium, provided the original author(s) and the source are credited.

\section{References}

Beck MA, Daniels WL, Eick M (2007) Leachate chemistry of mixtures of fly ash and alkaline coal refuse, presented at the 2007 World of Ash (WOCA) conference, Northern Kentucky, USA, $\mathrm{p} 8$

Black C, Voor BH, Sweetnich J (1996) Use of fluidized bed combustion ash for capping of refuse at the Tygart River Mine, In: Proceedings of the West Virginia Mine drainage task force annual meeting, Morgantown, 2-3 April 1996

Canon WC (1981) Mine safety and health administration report of investigation (preparation plant), impoundment accident, (failure of refuse pile). Preparation Plant (ID No. 15-11878), Eastover Mining Company, Brookside, p 10
Chugh YP, Mohanty S, Behum P, Nawrot J, Bell W, Chen S (2007) Identification and assessment of best management practices in Illinois mining operations to minimize sulfate and chlorine discharges. Final Report, ICCI Project DEV05, p 135

Chugh YP, Patwardhan A, Gurley H (2013) Effects of out-of-seam dilution on production, processing, environment and cost. In: International mineral processing technology conference, Bhubneswar, 6-8 December 2013, p 10

Daniels WL, Stewart BR (2000) Reclamation of Appalachian coal refuse disposal areas, reclamation of drastically disturbed lands, agronomy monograph. Am Soc Agron 41:433-459

Daniels WL, Stewart BR, Zelazny LW (1999) Characterization of acid leaching reactions in coal refuse/coal fly ash bulk blends. In: 1999 International ash utilization symposium on center for applied energy research, University of Kentucky, Paper no. 40, p 7

Demir I, Khan LA, Lytle JM (1999) Advances in coal cleaning. In: American Chemical Society, fuel preprint, presented at the American Chemical Society Annual Meeting, Anaheim, 1999, pp 110-114

Gluskoter HJ, Ruck RR, Miller WG, Cahill RA, Dreher GB, Kuhn JK (1977) Trace elements in coal: occurrence and distribution. Ill State Geol Surv Circ 499:154

Luttrell GH, Lineberry GT*, Adel G, Burchett RT (1996) Waste minimization through underground deshaling. In: Proceedings 14th annual workshop, Generic Mineral technology Center for mine safety and environmental engineering, Virginia Polytechnic Institute and State University, Blacksburg, 1996, pp 73-84

Mine Safety and Health Administration (2009) Engineering and design manual, coal refuse disposal facilities, 2nd edn, May 2006, D’Appolonia Engineers

National Research Council (NRC) (2002) Coal waste impoundments: risks, responses and alternatives. National Academy Press, Washington, D.C, p 230

Patwardhan A, Chugh YP, Moharana A, Hirschi J (2010) Cost and environmental impact of out-of-seam dilution on clean coal. International Coal Preparation Congress, Lexington, 20-25 April 2010

Rich DH, Hutchinson (1990) Neutralization and stabilization of combined refuse using lime kiln dust at high power mountain. In: Proceedings of the 1990 mining and reclamation conference, Charleston, vol 1, pp 55-60

Stewart BR, Daniels WL (1995) The impacts of coal refuse/fly ash bends on water quality and plant growth. In: presented at the 1995 National Meeting of the American Society for Surface Mining and Reclamation, Gillette, WY, 5-8 June 1995

Stewart B, Robinson G (1994) Mine safety and health administration report of investigation (preparation plant), non-injury inundation report, Martin County Coal Corporation, Preparation Plant (ID No. 15-03752), 1-C Mine (ID No. 15-03752), Davella, 23 May 1994, p 9

Stewart BR, Daniels WL, Zelazny LW, Jackson ML (2001) Evaluation of leachates from coal refuse blended with fly ash at different rates J Environ Qual 30(4 ):1382-1391

US Energy Information Administration (EIA) (2013) Annual coal report 2012, December 2013, p 68 